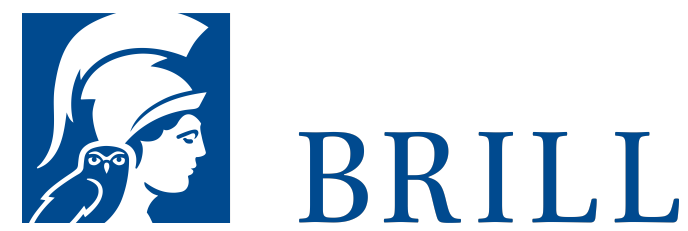

\title{
Imperatives and Other Directive Expressions in Latin
}

\author{
A Study in the Pragmatics of a Dead Language \\ Author: Rodie Risselada
}

As the recent hausse in pragmatic studies shows, linguistic attention is increasingly focussing on aspects of language use. Making use of recent insights developed within speech act theory, discourse analysis, and sociolinguistics, this book deals with the various expressions that were used in Latin to per-form so-called directive speech acts, i.e. orders, requests, advice, proposals, sug-gestions, etc. On the basis of a large corpus of comedy, correspondence, and instruction texts the expressions concerned (imperatives, subjunctives, future indicatives, as well as modal expressions and vari-ous other lexical expressions of directivity) are investigated against the background of the verbal interactions in which they typically occur. As regards its contribution to Latin linguistics, the present study adds a number of re-finements to our knowledge of this welldocumented lan-guage, for instance with respect to the reference of the subjects of the so-called impera-tive II ending in -to, the conventionalized speech act functions of interrogative quid and quin directives, and the diachronic process of conventionalization of velim requests.

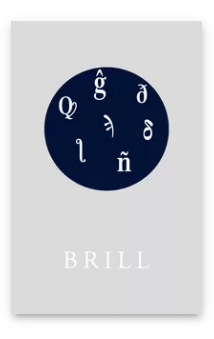

Pages: $361 \mathrm{pp}$.

Language:

English

Subjects: Greek

\& Latin

Literature,

Classical Studies

Publisher: Brill

Series:

Amsterdam

Studies in

Classical

Philology,

Volume: 2

E-Book (PDF)

Released online:

o1 Oct 2019

ISBN: $978-90-$

04-40897-5

List price

USD. Â $\$ 136.00$

Hardback

Publication date:

o1 Jan 1993

ISBN: $978-90-$

50-63206-5

List price

USD. Â $\$ 128.00$ 
For more information see brill.com

Order information: Order online at brill.com +44330 333 0049 | customerservices@brill.com Submission information: brill.com/authors

Titles published by Brill | Fink, Brill | mentis or Brill | Schöningh: +49(o)715413279216| brill@brocom.de 